\title{
Faktor - Faktor Yang Mempengaruhi Real Earnings Management Pada Perusahaan Manufaktur di BEI
}

\author{
Linda Santioso, Emily Janice, dan Andreas Bambang Daryatno \\ Fakultas Ekonomi dan Bisnis, Universitas Tarumanagara \\ Email: lindas@fe.untar.ac.id
}

\begin{abstract}
This research aims to find out and analyze the impact of audit committee financial expertise, audit quality that is proxied by external audit firm size, and profitability on real earnings management. The method used in this research was purposive sampling with a total sample of 59 manufacturing companies listed in Indonesian Stock Exchange (IDX). The type of data used was secondary data acquired through financial statements extracted from www.idx.co.id. Data analysis methods used in this research were classical assumption analysis, descriptive statistical test, $f$ test, $t$ test, and the test of determination coefficient. $T$ test was used to test this study's hypothesis. Final result of the study showed that audit committee financial expertise and audit quality proxied by external audit firm size do not have any significant effect on real earnings management, while profitability has been shown to have a positive effect on real earnings management.
\end{abstract}

Keywords: Real Earnings Management, Audit Committee Financial Expertise, Audit Quality, Profitability.

\begin{abstract}
Abstrak: Tujuan penelitian ini bertujuan untuk mengetahui dan menganalisa pengaruh keahlian keuangan komite audit, kualitas audit yang diproksikan dengan ukuran KAP, dan profitabilitas terhadap real earnings management. Metode penelitian yang digunakan dalam penelitian ini adalah menggunakan teknik purposive sampling. Jumlah sampel yang digunakan sebanyak 59 perusahaan manufaktur yang terdaftar di Bursa Efek Indonesia (BEI). Penelitian ini menggunakan data sekunder. Periode pengamatan adalah tahun 2016 sampai dengan tahun 2018. Semua data dan laporan keuangan maupun tahunan yang digunakan dalam penelitian ini diperoleh dari situs resmi Bursa Efek Indonesia yaitu www.idx.co.id. Dalam pengolahan data, penelitian ini menggunakan analisis data uji asumsi klasik, uji statistik deskriptif, uji f, uji t dan uji koefisien determinasi. Pengujian hipotesis dilakukan dengan uji t yang menunjukkan hasil bahwa keahlian keuangan komite audit dan kualitas audit tidak memiliki pengaruh terhadap real earnings management sedangkan profitabilitas mempumyai pengaruh positif terhadap real earnings management.
\end{abstract}

Kata Kunci: Real Earnings Management, Keahlian Keuangan Komite Audit, Kualitas Audit, Profitabilitas. 


\section{LATAR BELAKANG}

Sebagai pihak yang menerima wewenang dari pemilik perusahaan, manajer memiliki tanggung jawab untuk memaksimalkan kepentingan pemilik perusahaan. Namun manajer juga memiliki kepentingan sendiri yaitu untuk mensejahterakan dirinya sendiri. Adanya perbedaan kepentingan seperti itu dapat menimbulkan adanya konflik kepentingan yang memicu terjadinya praktik manajemen laba dalam perusahaan dimana manajemen berusaha mengintervensi penyusunan laporan keuangan perusahaan sehingga dapat menaikkan atau menurunkan laba akuntansi sesuai dengan kepentingannya sendiri.

Manajemen laba dapat dikategorikan menjadi manipulasi atau manajemen laba berbasis akrual dan berbasis riil (Real Earnings Management) dan cara penentuannya adalah berdasarkan apakah manipulasi laba tersebut mengarah kepada arus kas langsung. Manipulasi laba akrual biasa disebut sebagai manipulasi laba dengan metode dan perkiraanperkiraan akuntansi. Manipulasi laba riil merupakan manipulasi laba secara operasional perusahaan sehingga mempengaruhi arus kas secara langsung. Manajer dapat memanipulasi pendapatan dengan cara menawarkan diskon atau pembayaran kredit yang lebih fleksibel untuk meningkatkan penjualan, mengurangi beban-beban diskresioner, atau memproduksi lebih banyak barang untuk merendahkan tingkat harga pokok penjualan. Manajer biasanya menggunakan tiga jenis manipulasi yaitu manipulasi penjualan, pengurangan beban diskresioner, dan overproduksi.

Adanya kebebasan yang diberikan bagi perusahaan dalam memilih metode akuntansi yang akan dipergunakan menyebabkan manajemen perusahaan dapat dengan leluasa memilih berbagai kebijakan yang ada. Dengan adanya kebebasan tersebut memberikan celah bagi manajemen perusahaan untuk melakukan tindakan mengelola laba atau yang dikenal dengan istilah earnings management.Pihak manajemen yang dalam hal ini bertindak sebagai agent cenderung untuk melakukan manipulasi atas Laporan Keuangan dengan tujuan agar Laporan Keuangan terlihat lebih baik di mata para pemangku kepentingan yang dalam hal ini bertindak sebagai principal. Hal ini dilakukan pihak manajemen agar kinerja mereka terlihat bagus bagi pihak principal. Tindakan yang dilakukan oleh pihak manajemen ini tentu saja tidak benar dan menyalahi prinsip penyajian Laporan Keuangan yang mensyararkan harus transparan, tidak menyesatkan dan memiliki akuntabilitas. Selain itu tindakan yang dilakukan oleh pihak manajemen ini juga menyimpang dari tujuan utama perusahaan. Tindakan tersebut merupakan salah satu hal yang disebut sebagai manajemen laba.

Beberapa tahun sebelumnya terdapat beberapa kasus skandal besar di luar negeri yang memberikan dampak cukup besar terhadap integritas informasi akuntansi, etika praktikpraktik akuntansi dan pelaporan keuangannya. Pertama adalah kasus Enron yang cukup banyak memarik perhatian publik, dimana pada kasus ini perusahaan berusaha untuk memanipulasi laporan keuangan dengan tujuan agar terlihat bagus dengan cara meningkatkan menaikkan pendapatan fiktif sebesar US\$ 600 juta lebih. Kedua adalah kasus WorldCom yang merupakan salah satu perusahaan telekomunikasi terbesar di US. WorldCom ini melakukan kecurangan dengan memanipulasi laporan keuangannya sehingga tampak laba yang padahal sebenarnya perusahaan mengalami kerugian besar di tahun 2001, yaitu dengan cara tidak memunculkan adanya pelarian dana senilai US\$ 3,8 Milyar. Ketiga adalah kasus Xerox Corp, dimana perusahaan menaikkan pendapatan dan labanya dari tahun 1997-2000 yang dilakukan dengan mengakui terlebih dahulu pendapatan yang diperoleh 
dari kontrak-kontrak, dimana pendapatan ini seharusnya merupakan penerimaan di masa mendatang.

Kasus serupa juga terjadi di Indonesia dimana pada tahun 2002 sampai dengan 2003 lalu, laporan keuangan triwulan III tahun 2002 milik PT. Bank Lippo Tbk memiliki kejanggalan yang dapat dilihat oleh publik. Setelah diselidiki ternyata laporan keuangan PT. Bank Lippo Tbk yang muncul sebagai iklan di sebuah surat kabar harian nasional tertanggal 28 November 2002 tidak memiliki kesamaan informasi dengan laporan keuangan yang diberikan ke Bursa Efek Jakarta (BEJ). Didalam laporan tersebut terdapat juga pernyataan dari pihak manajemen bahwa laporan keuangan tersebut telah disusun berdasarkan Laporan Keuangan Konsolidasi yang telah diaudit oleh KAP Prasetio, Sarwoko dan Sandjaja dengan kesimpulan Penyertaan Wajar Tanpa Pengecualian.

Penyajian laporan keuangan tersebut dibuat dalam format perbandingan per 30 September 2002 (audited) dan per 30 September 2001 (unaudited). Dicantumkan juga didalam Laporan Keuangan, Nilai Agunan Yang Diambil Alih (“AYDA") per 30 September 2002 sebesar Rp. 2,393 triliun, total aktiva per 30 September 2002 sebesar Rp. 24,185 Triliun, Laba tahun berjalan per 30 September 2002 sebesar Rp. 98, 77 Miliar, dan Rasio Kewajiban Modal Minimum Yang Tersedia (CAR) sebesar 24,77\%. Pada laporan keuangan PT. Bank Lippo Tbk per 30 September 2002 yaitu tanggal yang sama dengan penyampaian laporan keuangan kepada Bursa Efek Jakarta (BEJ), diketahui bahwa kedua laporan keuangan tersebut berbeda. Laporan tersebut juga mencantumkan pernyataan manajemen PT. Bank Lippo Tbk bahwa Laporan Keuangan yang disampaikan adalah Laporan Keuangan "audited" yang tidak disertai dengan laporan auditor independen yang berisi opini Akuntan Publik.

Untuk mengatasi masalah kepercayaan publik dan mencegah terjadinya kasus-kasus seperti ini, ada sebuah bagian dalam Sarbanes-Oaxley Act (SOX) yang menyatakan adanya sebuah perubahan besar dalam persyaratan tata kelola perusahaan yang terdaftar di Amerika Serikat untuk meningkatkan kualitas pelaporan keuangan. (Cohen et al., 2008) menguji Real dan Accrual Earnings Management pada saat sebelum dan sesudah periode SOX tersebut. Dalam pengujian ini mereka menemukan adanya kenaikan pada tingkat Real Earnings Management setelah adanya SOX tersebut sedangkan tingkat Accrual Earnings Management justru menurun dalam periode yang bersamaan. Hasil yang didapatkan cukup untuk menyimpulkan bahwa sebuah perusahaan atau firma dapat menggunakan Real dan Accrual Earnings Management dan beralih antara satu dengan yang lainnya karena hasil akhirnya sulit dideteksi. Kecenderungan untuk menggunakan Real Earnings Management untuk mengelola laba merupakan sebuah tantangan bagi praktik tata kelola perusahaan di periode pasca SOX. Hal ini juga meningkatkan perhatian etis dari sikap manajerial.

Manajemen Laba Riil atau real earnings management dapat dipengaruhi oleh beberapa faktor seperti keahlian keuangan komite audit dimana kesadaran investor mengenai adanya Real Earnings Management banyak memunculkan pertanyaanpertanyaan terhadap kinerja keahlian keuangan komite audit. Keahlian keuangan komite audit diharapkan dapat mengurangi kecurangan dalam perusahaan dimana tugas utama dari komite audit adalah menelaah laporan keuangan dan informasi keuangan perusahaan atau firma yang akan disampaikan kepada publik, regulator, dan investor. Penelitian dari (Sun et al., 2014) mengungkapkan bahwa real earnings management yang terjadi secara agresif memiliki hubungan negatif terhadap keahlian keuangan komite audit, sedangkan penelitian 
dari (Sun et al., 2014) mengungkapkan keahlian keuangan komite audit berpengaruh positif terhadap real earnings management.

Kualitas Audit juga diduga memiliki andil dalam pelaksanaan Real Earning Management. Dalam sebuah perusahaan, auditor akan mengaudit laporan keuangan agar kesalahan material dapat ditemukan dan menghasilkan sebuah informasi yang berkualitas. Informasi yang berkualitas tersebut nantinya dapat mengurangi praktik manajemen laba. Kualitas audit juga dianggap berbeda antara KAP Big Four dan Non Big Four dimana KAP Big Four memiliki jaringan klien yang luas sehingga cenderung mempertahankan reputasinya dengan tidak mengambil klien perusahaan yang tingkat real earnings management nya tinggi (Kim dan Park, 2013). Namun sebaliknya, (Khanh dan Khuong, 2018) mengungkapkan tidak adanya perbedaan antara KAP Big Four dan non Big Four dalam masalah pengungkapan real earnings management. Penelitian dari (Alves, 2012) juga menyatakan bahwa KAP Big Four memiliki hubungan positif dengan aktivitas manajemen laba.

Faktor lain yang diduga berpengaruh terhadap Real Earnings Management adalah Profitabilitas. Profitabilitas menunjukkan kebolehan sebuah perusahaan dalam memperoleh laba bersih yang berkaitan dengan penjualan, total aset, maupun modal sendiri (Tala dan Karamoy, 2017). Tingkat profitabilitas yang tinggi menunjukkan bahwa perusahaan berhasil memperoleh laba yang tinggi. Laba sebuah perusahaan adalah tolak ukur yang digunakan oleh investor dalam berinvestasi dalam sebuah perusahaan. Semakin tinggi tingkat profitabilitas sebuah perusahaan maka perusahaan tersebut dianggap semakin menjanjikan dan dapat memberikan return yang besar untuk investor. Hal ini bisa jadi memotivasi para manajer untuk melakukan manipulasi laba riil.

Dalam menilai kinerja suatu perusahaan dasar yang paling sering digunakan adalah laporan keuangan. Laporan laba rugi (income statemtn) merupakan salah satu jenis laporan keuangan yang sering dijadikan sebagai tolak ukur dalam menilai keberhasilan operasional perusahaan untuk satu periode. Adanya fleksibilitas dalam pemilihan metode-metode akuntansi yang akan digunakan dalam penyusunan laporan keuangan akan mempengaruhi laba yang dihasilkan atau dilaporkan dalam laporan laba rugi. Sebagai contoh fleksibilitas dalam memilih metode penilaian persediaan apakah FIFO atau Average, metode penyusutan apakah straight line method atau accelerated method, dan metode pengakuan biaya produksi apakah direct costing atau absorption costing.

Dengan latar belakang tersebut diatas dan adanya perbedaan dalam beberapa penelitian sebelumnya, maka peneliti tertarik untuk meneliti kembali apakah Keahlian Keuangan Komite Audit, Kualitas Audit, dan Profitabilitas berpengaruh terhadap Real Earnings Management

\section{KAJIAN TEORI}

Teori Keagenan (Agency Theory). (Jensen, 1976) menyatakan Teori Keagenan adalah teori yang menjelaskan adanya agency conflict yang muncul karena adanya konflik kepentingan antara principal dan agent yang menimbulkan asimetri informasi diantara principal dan agent. Prinsip utama dari agency theory adalah terdapatnya hubungan kerja antara pihak yang memberi wewenang yaitu pemilik atau pemegang saham dengan pihak yang menerima wewenang (agent) yaitu manager dalam bentuk kerja sama (Primasari, 2011). Agen adalah pihak yang mendapat tanggung jawab secara moral dan professional 
untuk menjalankan tujuan perusahaan sebaik mungkin demi optimalisasi laba dan kinerja perusahaan. Dalam kontrak kerja antara principal dan agen tersebut dijelaskan tentang tanggung jawab secara moral dan professional seorang manajer atas dana yang diinvestasikan principal serta system pembagian hasil berupa keuntungan dan resiko oleh principal kepada agen yang telah disepakati bersama. Masalah keagenan seperti ini muncul karena adanya perbedaan pendapat dan perbedaan kepentingan antara pemilik dan manajemen.

Dengan adanya perbedaan kepentingan antara agent dan principal akan menimbulkan konflik kepentingan diantara manajemen perusahaan dengan pemilik perusahaan yang pada akhirnya akan memunculkan biaya keagenan (agency cost). Agent sebagai pihak yang memiliki informasi lebih mengenai keadaan perusahaan dituntut untuk dapat memberikan informasi secara lengkap kepada principal mengenai kinerja perusahaan. Akan tetapi terkadang informasi yang didapat principal tidak sesuai dengan fakta yang ada di dalam perusahaan. Hal ini terjadi karena manajer (agent) beranggapan bahwa mereka harus mendapatkan imbalan yang sama besarnya dengan tangggung jawab besar yang dibebankan kepada mereka. Di lain pihak, principal sebagai pihak yang memberi wewenang tugas kepada agent memiliki keterbatasan untuk mengakses informasi mengenai kinerja daripada agent dan informasi mengenai perusahaan secara menyeluruh. Hal inilah yang menimbulkan asimetri informasi antara principal dan agent.

Real Earnings Management. (Sun et al., 2014) menyatakan bahwa kegiatan manajemen laba melalui manipulasi aktivitias riil merupakan kegiatn yang berasal adari praktik operasional normal, yang dimotivasi oleh manajer. Hal ini dilakukan oleh manajer untuk membuat stakeholder dan pemegang saham percaya bahwa tujuan pelaporan keuangan telah dipenuhi dan dilakukan dalam operasi normal perusahaan. Ada beberapa hal yang digunakan oleh manajer dalam melakukan manajemen laba dengan manipulasi riil, seperti dengan mengurangi pengeluaran diskresioner dan memberikan diskon untuk menaikkan penjualan. Jika seorang manajer melakukan hal ini secara ekstensif dan berkesinambungan untuk mencapai target laba, maka tindakan itu dapat diartikan sebagai Real Earnings Management. Teknik yang dapat digunakan dalam real earnings management antara lain manajemen penjualan, overproduksi, dan pengurangan biaya diskresioner (Sun et al., 2014).

Contoh dari pengurangan biaya diskresioner dalam real earnings management antara lain mengurangi biaya iklan, biaya research and development atau riset dan pengembangan, biaya penjualan, biaya umum dan administrasi. Dengan mengurangi biaya-biaya tersebut, rekening utang pada akhir periode berkurang sampai di bawah normal dan hal tersebut berdampak kepada akrual abnormal yang positif. Pelaksanaan overproduction atau overproduksi dalam manipulasi laba riil berkaitan dengan pelaksanaan produksi perusahaan secara besar-besaran dimana manajer sebuah perusahaan manufaktur memproduksi barangbarang lebih dari yang dibutuhkan dengan tujuan mencapai permintaan yang diharapkan sehingga dapat meningkatkan laba. Kegiatan produksi dalam skala besar seperti ini akan memerlukan overhead cost yang tinggi, dan setelah dibagi dengan jumlah unit barang yang besar akan menyebabkan biaya rata-rata per unit dan harga pokok penjualan menurun. Penurunan harga seperti ini akan menyebabkan peningkatan margin operasi. 
Keahlian Keuangan Komite Audit. Masalah keagenen sering muncul ditengah-tengah konflik kepentingan antara pemegang saham perusahaan dengan manajer. Karena adanya konflik kepentingan tersebut, maka terciptalah asimetri informasi. Perusahaan harus memberikan laporan keuangannya untuk ditunjukkan kepada pemegang saham dalam keadaan apapun dan laporan keuangan tersebut tidak sesuai dengan keadaan perusahaan yang sebenarnya sehingga perlu adanya pengawasan terhadap proses pelaporan keuangan sebuah perusahaan. Hal itu menjadi tanggung jawab komite audit yang harus merangkap sebagai pengawas dan supervisor dalam mengawasi dewan komisioner dalam membuat laporan keuangan sebuah perusahaan.

Dalam definisi yang diberikan oleh Securities and Exchange Commission atau SEC, seorang ahli keuangan komite audit dikatakan sebagai seseorang yang memiliki: 1) Pengetahuan yang memadai mengenai Generally Accepted Accounting Principle (GAAP), 2) Kemampuan untuk menilai penerapan secara umum GAAP, 3) Pengalaman mempersiapkan, mangaudit, menganalisis, ataupun mengevaluasi laporang keuangan secara umum sebanding dengan yang diharapkan untuk dimasukkan keadalam laporan keuangan perusahaan 4) Memiliki pengertian yang baik mengenai kontrol internal terhadap pelaporan keuangan, dan 5) Memiliki pengertian yang baik mengenai fungsi komite audit. Menurut (Wardhani dan Joseph, 2010); (Susanto, 2016), keahlian keuangan anggota komite audit mengacu kepada anggota komite audit yang memiliki latar belakang pendidikan akuntansi dan memiliki pengalaman kerja dibidang akuntansi. Hal tersebut dianggap dapat meningkatkan kualitas laporan keuangan perusahaan dengan melakukan manipulasi atau manajemen laba berbasis riil.

Ada beberapa sifat komite audit yang dapat mempengaruhi efektivitas kerja komite audit. Penelitian-penelitian terdahulu menunjukkan bahwa keahlian keuangan komite audit dapat membuat anggota-anggota komite audit menganggap sepele proses pelaporan keuangan. Penelitian oleh (Sun et al., 2014) mengatakan bahwa kegiatan manajemen laba berhubungan negatif dengan adanya kemampuan akuntansi sebuah komite audit. Diperkuat lagi dengan penelitian (Dhaliwal et al., 2010) yang menemukan bahwa kualitas akrual lebih tinggi dalam komite audit yang memiliki setidaknya satu orang ahli keuangan dibandingkan yang tidak memiliki ahli keuangan dan (Sharma dan Kuang, 2019) bahwa efektivitas komite audit akan semakin kuat dengan adanya ahli keuangan. Komite audit yang memiliki setidaknya 1 orang ahli keuangan cenderung lebih membatasi terjadinya manajemen laba akrual, dengan ini dapat dikatakan bahwa anggota komite audit tersebut memiliki pengetahuan yang lebih dalam mengenai manajemen laba riil dan lebih berpengalaman dalam mendeteksi adanya manajemen laba riil.

Kualitas Audit. Kualitas audit adalah probabilitas dimana seorang auditor menemukan dan melaporkan adanya pelanggaran dalam system akuntansi auditnya (Christiani dan Nugrahanti, 2014). Dalam Financial Accounting Standards Board atau FASB, tertulis bahwa laporan keuangan harus memenuhi dua karakteristik yaitu relevansi (relevance) dan keandalan (reliability). Menurut (Singgih dan Bawono, 2010) karakteristik-karakteristik tersebut tidak mudah diukur sehingga siapapun yang tergolong pengguna informasi memerlukan jasa pihak ketiga berupa auditor independen yang bertanggung jawab memberi jaminan bahwa laporan keuangan sebuah perusahaan benar-benar relevan dan dapat diandalkan sehingga pihak yang memiliki kepentingan dengan perusahaan percaya dengan pelaporan keuangan perusahaan tersebut. Auditor independen sering disebut sebagai 
akuntan publik yang berpedoman sesuai dengan ketentuan Institut Akuntan Publik Indonesia (IAPI) dan bekerja dalam Kantor Akuntan Publik (KAP).

Audit eksternal memiliki peran yang penting dalam mengatasi asimetri informasi antara manajer dengan pemegang saham dengan cara memastikan keandalan dan kejujuran dari pelaporan keuangan sebuah perusahaan. Ada beberapa hal yang membedakan kualitas audit yang dihasilkan oleh KAP Big Four (Kantor Akuntan Publik yang terkenal) dan KAP yang bukan Big Four. KAP Big Four bersifat lebih konservatif dalam memitigasi manajemen laba yang dikarenakan reputasinya yang baik dan dipercaya klien-klien dari berbagai kalangan dan Negara (Khanh dan Kuong, 2018).

Selain itu, menurut (Alzoubi, 2017), KAP Big Four diharapkan memiliki lebih banyak sumber daya seperti jumlah staff, keahlian para auditornya, anggaran, dan teknologi yang mendukung prosedur-prosedur ekstensif dalam mendeteksi adanya manajemen laba. Hal ini diperkuat dengan penelitian dari (Boedhi dan Ratnaningsih, 2015) KAP besar akan termotivasi untuk menjaga reputasinya karena apabila terjadi kesalahn pada penyajian dalam audit hal tersebut akan kehilangan kepercayaan publik. Selain itu, kantor-kantor akuntan publik yang memiliki hubungan kerjasama dengan KAP Big Four mempunyai pengetahuan dan pengalaman yang lebih mengenai audit laporan keuangan.

Profitabilitas. Profitabilitas adalah kemampuan yang dilakukan perusahaan untuk menghasilkan laba dan tingkat keuntungan dimasa mendatang, dan dapat dijadikan acuan sebagai tolak ukur keberhasilan operasi perusahaan. Dengan demikian, investor yang berinvestasi jangka panjang akan dengan sungguh-sungguh mempertimbangkan analisis profitabilitas. Contohnya dapat dilihat dalam sikap para pemegang saham yang selalu mempertimbangkan laba yang diterima dalam bentuk dividen. Menurut (Sabrin et al., 2016), rasio profitabilitas merupakan cara untuk mengukur kemampuan perusahaan dalam menghasilkan laba dengan keterkaitan penjualan, total asset dan modal sendiri. Rasio ini akan dipertimbangkan oleh para investor dan pemegang saham karena berhubungan dengan deviden dan harga saham yang akan diterima oleh investor.

(Wiyadi, 2016) Profitabilitas mencerminkan berhasilnya sebuah perusahaan dalam memperoleh dan menghasilkan keuntungan. Rasio yang digunakan dalam pengukuran profitabilitas adalah Return of Assets (ROA) yaitu rasio kemampuan perusahaan dalam menghasilkan laba atau keuntungan yang tersedia untuk pemegang saham perusahaan tersebut. Return of Assets yang tinggi dari tahun ke tahun dalam suatu perusahaan mengindikasikan adanya peningkatan laba bersih sedangkan peningkatan laba bersih perusahaan menunjukkan bahwa nilai perusahaan meningkat karena tingginya tingkat laba dapat mempengaruhi harga saham dan nilai perusahaan.

Dalam melakukan tugas dan tanggung jawabnya, manajer memiliki motivasi untuk mencapai atau bahkan melampaui target laba perusahaan. Biasanya manajer berusaha untuk tidak melaporkan kerugian perusahaan (Khanh dan Kuong, 2018). Hal ini menjadi alasan manajer untuk dapat melakukan manajemen laba riil. Selain itu, dalam pelaksanaan Initial Public Offering dan Seasoned Equity Offering, profitabilitas juga menjadi salah satu titik perhatian. Investor akan mempertimbangkan apakah perusahaan ini layak untuk diinvestasikan melalui penghasilan perusahaannya. Karena hal ini, perusahaan-perusahaan lebih memperhatikan citra dan performanya dengan memperbaiki nilai dan laba perusahaan. Hal ini didukung dengan riset yang menunjukkan bahwa perusahaan yang berada dalam kondisi financial distress cenderung akan menunjukkan penghasilan yang sudah didongkrak secara agresif pada SEO (Seasoned Equity Offering). 
Berikut merupakan Model Penelitian dalam penelitian ini:

Gambar 1. Model Penelitian dan Hipotesis

Variabel Independen

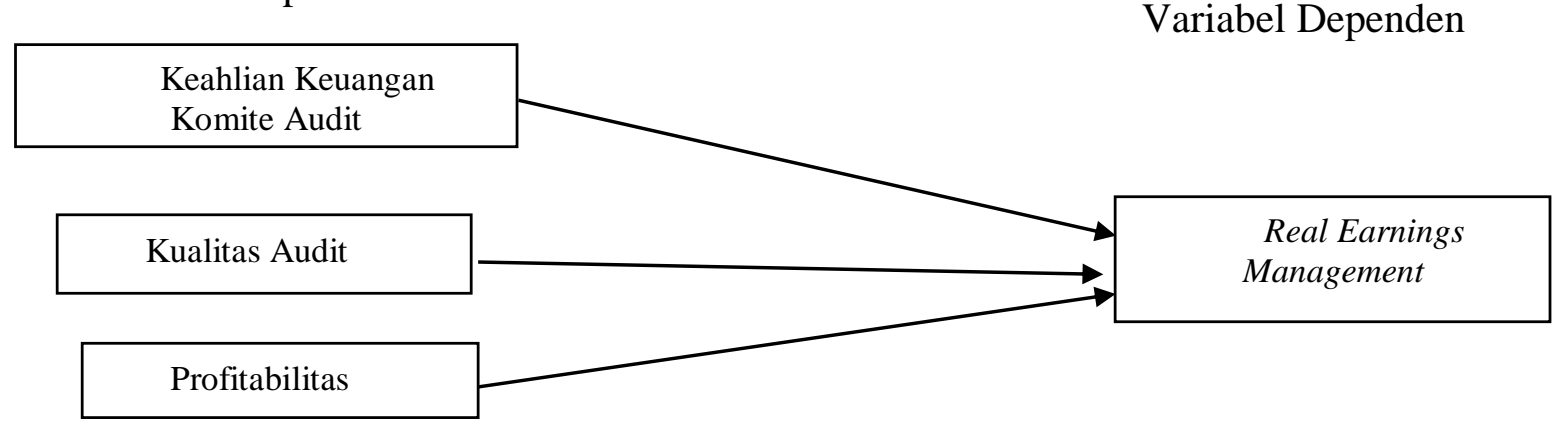

Hipotesis Penelitian:

H1: Keahlian Keuangan Komite Audit berpengaruh negatif terhadap Real Earnings Management.

H2: Kualitas Audit berpengaruh negatif terhadap Real Earnings Management.

H3: Profitabilitas berpengaruh positif terhadap Real Earnings Management.

\section{METODOLOGI}

Penelitian ini bertujuan untuk menguji pengaruh variabel independen (keahlian keuangan komite audit, kualitas audit, dan profitabilitas) dengan variabel dependen (real earnings management). Metode penelitian yang digunakan bersifat kuantitatif dengan desain penelitian bersifat kausal. Data sekunder yang digunakan dalam penelitian ini diperoleh dari laporan keuangan dan tahunan perusahaan manufaktur yang terdaftar di BEI pada periode 2016-2018, dimana data-data tersebut diperoleh melalui www.idx.co.id. Populasi penelitian ini berupa perusahaan manufaktur yang terdaftar di Bursa Efek Indonesia (BEI) pada tahun 2016 - 2018 dengan teknik pengambilan sampel yang digunakan adalah metode purposive sampling. Berikut merupakan beberapa kriteria yang digunakan untuk pengambilan sampel: (1) Subyek penelitian adalah perusahaan manufaktur yang terdaftar di Bursa Efek Indonesia pada periode tahun 2016-2018. (2) Subyek penelitian adalah perusahaan yang tidak mengalami kerugian material selama periode 2016-2018. (3) Subyek penelitian adalah perusahaan yang memiliki laporan keuangan yang disajikan dalam mata uang Rupiah (IDR) selama periode 2016-2018. (4) Subyek penelitian adalah perusahaan yang memiliki informasi yang dibutuhkan terkait komite audit. (5) Subyek penelitan adalah perusahaan yang memiliki data lengkap baik dalam laporan keuangan maupun tahunan pada periode 2016-2018

Penelitian ini menggunakan tiga variabel independen dan satu variabel dependen. Variabel independen yang digunakan dalam penelitian ini yaitu keahlian keuangan komite audit (ACFE), kualitas audit (AQL) dan profitabilitas (ROA), sedangkan variabel dependen adalah Real Earnings Management. 
Real Earnings Management menurut (Sun et al., 2014) dapat diukur dengan menggunakan beberapa dasar penghitungan, yakni CFO (cash flow operating), biaya produksi yang tidak normal, dan pengeluaran beban diskresioner yang tidak normal. Dalam penelitian ini variabel dependen yaitu Real Earnings Management diukur dengan menggunakan rumus arus kas operasional atau CFO, karena real earnings management akan mempengaruhi arus kas perusahaan melalui kegiatan-kegiatan operasional yang dilakukan oleh perusahaan. Sehingga Real Earnings Management dapat dihitung dengan menggunakan rumus:

$$
\frac{C F O_{t}}{T A_{t-1}}=\alpha 0\left(\frac{1}{T A_{t-1}}\right)+\alpha 1\left(\frac{S_{t}}{T A_{t-1}}\right)+\alpha 2\left(\frac{\Delta S_{t}}{T A_{t-1}}\right)+\varepsilon
$$

Sesuai penelitian yang dilakukan oleh (Sun et al., 2014), dalam penelitian ini Keahlian Keuangan Komite Audit dapat dihitung dengan menggunakan rumus:

Keahlian Keuangan Komite Audit = Jumlah anggota komite audit yang memiliki pengalaman kerja atau latar belakang pendidikan di bidang akuntansi atau keuangan.

Dalam penelitian ini, kualitas audit diukur dengan variabel dummy dimana sebuah perusahaan diberikan nilai " 1 " apabila diaudit secara eksternal oleh KAP big four dan " 0 " apabila diaudit secara eksternal oleh KAP non big four (Khanh dan Kuong, 2018).

Sesuai dengan penelitian yang dilakukan oleh (Khanh dan Kuong, 2018), dalam penelitian ini Profitabilitas dapat dihitung dengan menggunakan rumus:

$$
\mathrm{ROA}=\frac{\text { Net Income }}{\text { Total Asset }}
$$

Program pengolahan data yang digunakan dalam penelitian ini adalah dengan menggunakan perangkat lunak E-Views 10. Penelitian ini melakukan beberapa pengujian yang terdiri atas uji statistik deskriptif dan uji asumsi klasik untuk menentukan estimasi model data panel yang tepat, seperti common effect model, random effect model, fixed effect model, uji Chow, uji Hausman, uji Lagrange Multiplier (uji LM). sedangkan dalam pengujian hipotesis dilakukan beberapa pengujian, seperti uji $\mathrm{F}$, uji adjusted $\mathrm{R}^{2}$, serta uji $\mathrm{t}$.

\section{HASIL UJI STATISTIK Statistik Deskriptif}

Tabel 1. Hasil Analisis Statistik Deskriptif

\begin{tabular}{l|l|l|l|l}
\hline & REM & ACFE & AQL & ROA \\
\hline Mean & 0.183926 & 2.005650 & 0.435028 & 0.083145 \\
\hline Median & 0.162290 & 2.000000 & 0.000000 & 0.056400 \\
\hline Maximum & 0.437820 & 3.000000 & 1.000000 & 0.526700 \\
\hline Minimum & 0.049380 & 0.000000 & 0.000000 & 0.000280 \\
\hline Std. Dev & 0.087312 & 0.719036 & 0.497167 & 0.088357 \\
\hline
\end{tabular}




\begin{tabular}{l|l|l|l|l}
\hline Skewness & 0.625180 & -0.192239 & 0.262109 & 2.521246 \\
\hline Kurtosis & 2.393212 & 2.464028 & 1.068701 & 10.50867 \\
\hline Jarque Berra & 14.24551 & 3.208786 & 29.53481 & 603.3251 \\
\hline Probability & 0.0008007 & 0.201011 & 0.000000 & 0.000000 \\
\hline Sum & 32.55497 & 355.0000 & 77.00000 & 14.71658 \\
\hline Dev & 1.341704 & 90.99435 & 43.50282 & 1.374033 \\
\hline Observations & 177 & 177 & 177 & 177 \\
\hline
\end{tabular}

Analisis Statistik Deskriptif. Penelitian ini menggunakan teknik analisis statistik deskriptif sebelum analisis regresi dilakukan. Menurut (Ghozali, 2013), analisis statistik deskriptif adalah statistik yang memberikan gambaran data atau mendeskripsikan data penelitian dapat dilihat dari nilai rata-rata atau mean dengan tujuan untuk mengetahui nilai rata-rata dari sampel penelitian, standar deviasi untuk mengetahui persebaran data dalam sampel penelitian, nilai maksimum untuk mengetahui nilai terkecil sampel penelitian sehingga informasi data menjadi lebih jelas.

Pengujian ini dilakukan untuk menunjukkan karakteristik suatu data melalui mean (rata-rata), nilai maksimum, nilai minimum, standar deviasi dari setiap variabel yang diuji. dalam periode 2016 sampai dengan 2018 menunjukkan nilai mean untuk real earnings management adalah sebesar 0.183926 , nilai minimum sebesar 0.049380 , nilai maksimum sebesar 0.437820 dan standar deviasi sebesar 0.087312. Untuk variabel keahlian keuangan komite audit hasil statistik deskriptif menunjukkan nilai mean sebesar 2.005650, nilai minimum dan maksimum sebesar 0 dan 3, dan standar deviasi sebesar 0.719036. Kemudian untuk variabel kualitas audit memiliki nilai mean sebesar 0.435028 , nilai minimum dan maksimum sebesar 0.000000 dan 1.000000 , nilai standar deviasi sebesar 0.497167 . Terakhir untuk variabel profitabilitas menunjukkan nilai mean sebesar 0.083145 , nilai minimum dan maksimum sebesar 0.000280 dan 0.526700 juga standar deviasi sebesar 0.088357 .

\section{Hasil Uji Asumsi Analisis Data}

Uji Chow. Keuntungan menggunakan data panel dalam sebuah penelitian beberapanya adalah: 1) dapat mendeteksi dan mengukur sebuah efek secara sederhana, 2) dengan adanya kombinasi, informasi yang diberikan oleh data akan semakin baik, 3) Data panel dapat memperkecil bias ketika meregresikan suatu data kedalam agregasi yang lebih luas (Gujarati, 2012). Pengolahan data dalam penelitian ini akan menggunakan aplikasi atau software EVIEWS 10 dengan tingkat kesalahan sebesar 0,05. Dalam pengoperasiannya, data panel memiliki beberapa model yaitu Common Effect Model, Fixed Effect Model, dan Random Effect Model.

Penelitian ini melakukan pengujian estimasi mode data panel dengan melakukan uji Chow dan uji Hausman.

Berikut ini hasil dari uji chow:

Tabel 2. Hasil Uji Chow

\begin{tabular}{lccc}
\hline \hline Effects Test & Statistic & d.f. & Prob. \\
\hline \hline Cross-section F & 13.950394 & $(58,115)$ & 0.0000
\end{tabular}




\begin{tabular}{llll} 
Cross-section Chi-square & 368.852587 & 58 & 0.0000 \\
\hline
\end{tabular}

Cross-section fixed effects test equation:

Dependent Variable: REM

Method: Panel Least Squares

Date: 01/07/20 Time: 18:12

Sample: 20162018

Periods included: 3

Cross-sections included: 59

Total panel (balanced) observations: 177

\begin{tabular}{crrrr}
\hline \hline Variable & Coeficient & Std. Error & t-Statistic & Prob. \\
\hline \hline C & 0.167693 & 0.020067 & 8.356681 & 0.0000 \\
ACFE & -0.003007 & 0.008924 & -0.336914 & 0.7366 \\
AQL & 0.006127 & 0.014600 & 0.419664 & 0.6753 \\
ROA & 0.235706 & 0.082174 & 2.868394 & 0.0046
\end{tabular}

Sumber: (Hasil pengolahan data menggunakan EViews 10, 2020)

Tujuan dan fungsi uji chow adalah untuk membandingkan common effects model dengan fixed effect model sehingga dapat diketahui model apa yang paling tepat digunakan untuk penelitian ini. Hasil pengujian menunjukkan bahwa hasil uji Redundant Fixed Effect Test atau disebut juga dengan Uji Chow menunjukkan hasil 0.0000 lebih kecil dari pada 0,05 atau 5\%. Pada tingkat signifikansi sebesar 5\%, apabila nilai cross-section $F$ dan cross section chi-square lebih kecil daripada 0,05 maka kesimpulannya adalah H0 ditolak dan H1 diterima. Dimana $\mathrm{H} 0$ adalah common effect model dan $\mathrm{H} 1$ adalah fixed effect model.

Dari hasil yang diperoleh, diketahui bahwa model yang paling tepat untuk penelitian ini adalah Fixed Effect Model.Walaupun begitu, perlu dilakukan lagi uji selanjutnya yang membandingkan antara Fixed Effect Model dengan Random Effect Model. Uji yang digunakan untuk menguji perbandingan Fixed Effect Model dengan Random Effect Model adalah Uji Hausman. Sebelum melakukan Uji Hausman, perlu dilakukan uji Random Effect Model. Pendekatan random effect model dilaksanakan jika terdapat data cross section yang lebih banyak jika dibandingkan dengan data time series.

\section{Uji Hausman}

Tabel 3. Hasil Uji Hausman

\begin{tabular}{lrrr}
\hline \hline Test Summary & $\begin{array}{r}\text { Chi-Sq. } \\
\text { Statistic }\end{array}$ & Chi-Sq. d.f. & Prob. \\
\hline \hline Cross-section random & 0.657260 & 3 & 0.8832 \\
\hline \hline
\end{tabular}

Cross-section random effects test comparisons:

Variable $\quad$ Fixed Random Var(Diff.) Prob.




\begin{tabular}{crrrr}
\hline \hline ACFE & 0.002636 & 0.000537 & 0.000074 & 0.8075 \\
AQL & -0.015126 & -0.006321 & 0.000184 & 0.5159 \\
ROA & 0.270131 & 0.268305 & 0.012337 & 0.9869 \\
\hline \hline
\end{tabular}

Fungsi dari Uji Hausman adalah untuk menentukan apakah Fixed Effect Model ataukah Random Effect Model yang lebih tepat untuk suatu penelitian dengan cara membandingkan kedua pendekatan tersebut.

Setelah diuji dengan menggunakan Uji Hausman yang disajikan pada Tabel 3 ditemukan bahwa nilai probabilitas Cross-section random adalah sebesar 0.8832 dimana angka tersebut lebih besar dari 0.05 atau $5 \%$. Dengan menggunakan tingkat signifikansi sebesar 5\% dimana jika probabilitas Cross-section random lebih kecil dari 0.05 maka $\mathrm{H} 0$ ditolak dan apabila lebih besar daripada 0.05 maka H0 diterima. Dari sana dapat disimpulkan bahwa hipotesis yang diperoleh dari uji Hausman ini adalah:

\section{H0: Random Effects Model}

H1: Fixed Effects Model

Hasil pengujian dengan menggunakan Correlated Random Effect atau Uji Hausman menunjukkan bahwa pendekatan yang tepat untuk digunakan dalam penelitian ini adalah model random effect. Akan tetapi ditemukan ketidaksamaan antara hasil uji Chow dengan hasil uji Hausman, dimana uji Chow menunjukkan bahwa pendekatan yang lebih tepat digunakan dalam penelitian ini adalah fixed effect model, sedangkan uji Hausman menunjukkan bahwa pendekatan random effect model adalah pendekatan yang lebih tepat untuk digunakan dalam penelitian ini. Oleh dari itu diperlukan pengujian lagi yaitu uji Lagrange Multiplier untuk memastikan mana pengujian yang lebih tepat.

Uji Lagrange Multiplier. Uji Lagrange Multiplier digunakan untuk mengetahui apakah Pooled Least Square (PLS) ataukah Random Effect Model yang lebih tepat digunakan sebagai model regresi berganda dalam suatu data panel. Berikut hasil uji Lagrange Multiplier:

Tabel 4. Uji Lagrange Multiplier

\begin{tabular}{lccl}
\hline \hline $\begin{array}{l}\text { Null (no rand. Effect) } \\
\text { Alternative }\end{array}$ & $\begin{array}{c}\text { Cross-section } \\
\text { One-sided }\end{array}$ & $\begin{array}{c}\text { Period } \\
\text { One-sided }\end{array}$ & Both \\
\hline \hline Breusch-Pagan & 116.3990 & 0.621746 & 117.0208 \\
& $(0.0000)$ & $(0.4304)$ & $(0.0000)$ \\
Honda & 10.78884 & -0.788509 & 7.071301 \\
& $(0.0000)$ & $(0.7848)$ & $(0.0000)$ \\
King-Wu & 10.78884 & -0.788509 & 1.194508 \\
GHM & $(0.0000)$ & $(0.7848)$ & $(0.1161)$ \\
& -- & -- & 116.3990 \\
& -- & -- & $(0.0000)$ \\
\hline \hline
\end{tabular}


Sumber: (Hasil pengolahan data menggunakan Eviews 10, 2020)

Dengan melihat hasil pengujian Lagrange Multiplier yang tersaji di tabel 4, dapat diketahui bahwa nilai probabilitas Breusch-Pagan dalam kolom Cross-Section adalah sebesar 0.0000 atau bisa dikatakan lebih kecil dari 0.05. Dalam tingkat signifikansi 5\%, apabila nilai probabilitas Breusch-Pagan lebih kecil daripada 0.05 maka H0 ditolak namun sebaliknya, apabila nilai probabilitas Breusch-Pagan lebih besar dari 0.05 maka dapat disimpulkan bahwa H0 diterima. Dari sana dapat disimpulkan bahwa hipotesis yang diperoleh dari uji

\section{H0: Common Effects Model}

H1: Random Effects Model

Dengan hasil pengujian diatas maka dapat dikatakan bahwa pendekatan dengan Random Effect Model adalah model yang lebih tepat digunakan dalam penelitian ini karena nilai Breusch-Pagan yang ditunjukkan dalam kolom Cross-Section lebih kecil dari 0.05. Hal tersebut dapat terjadi karena dalam hasil pengujian Uji Hausman dan Uji Lagrange Multiplier ditemukan bahwa pendekatan dengan memakai metode random effect model merupakan pendekatan yang paling sesuai untuk digunakan dalam penelitian ini.

\section{Hasil Uji Regresi}

Tabel 5. Hasil Uji Regresi

\begin{tabular}{crrrr}
\hline \hline Variable & Coefficient & Std. Error & t-Statistic & \multicolumn{1}{c}{ Prob. } \\
\hline \hline C & 0.163291 & 0.025001 & 6.531481 & 0.0000 \\
ACFE & 0.000537 & 0.009809 & 0.054767 & 0.9564 \\
AQL & -0.006321 & 0.015323 & -0.412556 & 0.6804 \\
ROA & 0.268305 & 0.095598 & 2.806608 & 0.0056 \\
\hline
\end{tabular}

Sumber: (Hasil pengolahan data menggunakan Eviews 10, 2020)

Hipotesis pada penelitian ini menggunakan pengujian model regresi linear berganda, dimana model regresi linear berganda yang dimaksud adalah sebagai berikut :

$$
\mathrm{REM}=0.163291+0.000537(\mathrm{ACFE})-0.006321(\mathrm{AQL})+0.268305(\mathrm{ROA})+\varepsilon
$$

Berdasarkan model penelitian yang ditampilkan diatas menunjukan pengaruh variabel-variabel independen dalam penelitian yaitu keahlian keuangan komite audit, kualitas audit, dan profitabilitas terhadap variabel dependen yaitu Real Earnings Management. Berdasarkan persamaan regresi yang telah dirumuskan tersebut diperoleh nilai konstanta sebesar 0.163291. Hal ini menunjukan bahwa Real Earnings Management akan memiliki nilai sebesar 0.163291 satuan apabila besarnya keahlian keuangan komite audit, kualitas audit, dan profitabilitas adalah konstan. 
Koefisien regresi variabel keahlian keuangan komite audit (ACFE) yang diperoleh adalah sebesar 0.000537 yang menunjukan jika nilai keahlian keuangan komite audit mengalami kenaikan sebesar satu satuan, maka real earnings management akan mengalami peningkatan sebesar 0.000537 dengan asumsi bahwa variabel kualitas audit dan profitabilitas adalah konstan. Begitu pula sebaliknya, apabila nilai keahlian keuangan komite audit meenurun sebesar satu satuan, maka real earnings management juga akan mengalami penurunan sebesar 0.000537 dengan asumsi bahwa variabel keahlian keuangan komite audit dan kualitas audit adalah bernilai konstan.

Koefisien regresi variabel kualitas audit yang diperoleh adalah sebesar -0.006321 . Hal ini menunjukan apabila nilai kualitas audit mengalami pensebesar satu satuan, maka real earnings management akan mengalami penurunan sebesar 0.006321 dengan asumsi bahwa variabel keahlian keuangan komite audit dan profitabilitas adalah konstan. Begitu pula sebaliknya, apabila nilai kualitas audit mengalami penurunan sebesar satu satuan, maka real earnings management akan mengalami kenaikan sebesar 0.006321 dengan asumsi bahwa variabel keahlian keuangan komite audit dan profitabilitas adalah konstan.

Koefisien regresi variabel profitabilitas yang diperoleh adalah sebesar 0.268305 . Hal ini menunjukan apabila nilai profitabilitas mengalami kenaikan sebesar satu satuan, maka real earnings management akan mengalami peningkatan sebesar 0.268305 dengan asumsi bahwa variabel keahlian keuangan komite audit dan kualitas audit adalah konstan. Begitu pula sebaliknya, apabila nilai profitabilitas mengalami penurunan sebesar satu satuan, maka real earnings management akan mengalami penurunan sebesar 0.268305 dengan asumsi bahwa variabel keahlian keuangan komite audit dan kualitas audit adalah konstan.

\section{Uji F (Signifikansi Simultan)}

Tabel 6. Hasil Uji F (Uji Signifikansi Simultan)

\begin{tabular}{llll}
\hline \hline \multicolumn{4}{c}{ Weighted Statistics } \\
\hline \hline R-squared & 0.044576 & Mean dependent var & 0.048003 \\
Adjusted R-squared & 0.028008 & S.D. dependent var & 0.037093 \\
S.E. of regression & 0.036570 & Sum squared resid & 0.231367 \\
F-statistic & 2.690491 & Durbin-Watson stat & 1.758759 \\
Prob(F-statistic) & 0.047877 & & \\
\hline \hline
\end{tabular}

Sumber: (Hasil pengolahan data menggunakan Eviews 10, 2020)

Uji $\mathrm{F}$ bertujuan untuk mengetahui kelayakan model regresi yang digunakan dalam sebuah penelitian juga untuk mengetahui apakah variabel bebas atau variabel independen secara serentak berpengaruh terhadap variabel terikat. Apabila signifikansi atau sig Uji $\mathrm{F}$ menunjukkan angka $\geqq 0.05$ maka dapat disimpulkan bahwa variabel tidak bebas atau $\mathrm{H} 0$ tidak ditolak. Hal tersebut berarti tidak ada variabel independen yang dapat digunakan untuk memprediksi variabel dependen. Apabila hasil Uji F menunjukkan nilai signifikansi $<0.05$ maka model yang terbentuk sudah memenuhi kriteria kelayakan regresi atau H0 ditolak dan Ha tidak ditolak. Dengan begitu, dapat disimpulkan bahwa model data yang terbentuk dalam penelitian tersebut layak digunakan. 
Hasil pengujian signifikansi simultan pada penelitian ini menunjukkan nilai signifikansinya adalah sebesar 0.047877 . Nilai signifikansi dalam penelitian ini lebih kecil dari nilai signifikansi yang telah ditetapkan, yaitu sebesar 5\% atau 0.05 . Hal ini menyatakan bahwa keahlian keuangan komite audit, kualitas audit, dan profitabilitas berpengaruh secara simultan terhadap earnings response coefficient (ERC) dan model penelitian dapat dinyatakan layak.

Uji Adjusted $\mathbf{R}^{2}$ (Uji Koefisien Determinasi). Uji koefisien determinasi mengukur kemampuan masing-masing variabel independen dalam menjelaskan variabel dependen. Apabila nilai uji koefisien determinasi semakin mendekati angka nol, hal tersebut berarti kemampuan variabel independen dalam menjelaskan variabel dependen lebih lemah namun apabila nilai uji koefisien determinasi semakin mendekati angka satu maka kemampuan variabel independen menjelaskan variabel dependen lebih kuat.

Dalam tabel 6 dapat dilihat bahwa nilai adjusted $r$-squared adalah sebesar 0.028008 atau sebesar 2.8\%. Hal ini memiliki arti bahwa variabel Keahlian Keuangan Komite Audit (ACFE), Kualitas Audit (AQL), dan Profitabilitas (ROA) dalam memprediksi variabel Real Earnings Management (REM) adalah sebesar 2.8\% sedangkan masih terdapat $97.2 \%$ faktor lain yang dapat mempengaruhi Real Earnings Management (REM) di luar Keahlian Keuangan Komite Audit (ACFE), Kualitas Audit (AQL), dan Profitabilitas (ROA).

Berikut terlampir tabel hasil uji signifikansi parameter individual:

Tabel 7. Uji Signifikansi Parameter Individual

\begin{tabular}{crrrr}
\hline \hline Variable & Coefficient & Std. Error & t-Statistic & \multicolumn{1}{c}{ Prob. } \\
\hline \hline C & 0.163291 & 0.025001 & 6.531481 & 0.0000 \\
ACFE & 0.000537 & 0.009809 & 0.054767 & 0.9564 \\
AQL & -0.006321 & 0.015323 & -0.412556 & 0.6804 \\
ROA & 0.268305 & 0.095598 & 2.806608 & 0.0056 \\
\hline \hline
\end{tabular}

Sumber: (Hasil pengolahan data menggunakan Eviews 10, 2020)

Uji t (Uji Signifikansi Parameter Individual). Pengujiannya ini bertujuan untuk mengetahui apakah masing-masing variabel independen terhadap variabel dependen mempunyai pengaruh yang signifikan secara parsial atau individu, dengan asumsi masingmasing variabel independen bersifat konstan. Uji t merupakan pengujian yang dilakukan untuk mengetahui apakah masing-masing variabel berpengaruh terhadap variabel independen. Kriteria yang digunakan dalam uji t adalah apabila nilai signifikansi < alpha $(\alpha$ $=0.05$ ) maka Ho ditolak dan Ha diterima. Hal ini menunjukan bahwa terdapat pengaruh secara parsial antara variabel independen terhadap variabel dependen namun bila nilai signifikansi $\geq$ alpha $(\alpha=0.05)$ maka Ho diterima dan Ha ditolak. Hal ini berarti tidak ada pengaruh secara parsial antara variabel independen dengan variabel dependen.

Dalam tabel 7 diketahui bahwa variabel keahlian keuangan komite audit (ACFE) memiliki nilai probabilitas sebesar 0.9564 yang lebih besar dari 0.05 , oleh karena itu, dapat 
disimpulkan bahwa variabel keahlian keuangan komite audit tidak berpengaruh terhadap real earnings management (REM).

Sesuai hasil yang ditampilkan pada tabel 7 diketahui bahwa variabel kualitas audit (AQL) memiliki nilai probabilitas sebesar 0.6804 dimana angka tersebut lebih besar dari 0.05 , oleh karena itu dapat disimpulkan bahwa variabel kualitas audit tidak memiliki pengaruh terhadap real earnings management (REM).

Sesuai hasil yang ditampilkan pada tabel 7 diketahui bahwa variabel profitabilitas (ROA) memiliki nilai profitabilitas sebesar 0.0056 dimana angka tersebut lebih kecil dari 0.05 dan juga memiliki koefisien sebesar 0.268305. Oleh karena itu, dapat disimpulkan bahwa variabel kualitas audit memiliki pengaruh terhadap real earnings management (REM).

\section{PEMBAHASAN}

Pada penelitian ini keahlian keuangan komite audit tidak memiliki pengaruh yang signifikan terhadap real earnings management (REM). Keahlian Keuangan Komite Audit merepresentasikan jumlah anggota suatu komite audit perusahaan yang memiliki pengalaman atau latar belakang pendidikan di bidang akuntansi ataupun keuangan (finance). Ada atau tidaknya seorang ahli dalam komite audit perusahaan tidak dapat menjamin bahwa real earnings management akan terjadi.

Tidak berpengaruhnya Keahlian Keuangan Komite Audit ini mungkin terjadi karena walaupun adanya kenyataan bahwa pembentukan komite audit yang memiliki pengalaman atau pendidikan di bidang akuntansi atau keuangan hanya berdasarkan pada peraturan yang berlaku sehingga tidak begitu berfungsi dalam memaksimalkan kompetensi dalam medeteksi manajemen laba pada perusahaan (Sari, 2017). Penelitian terdahulu yang mengatakan bahwa Keahlian Keuangan Komite Audit tidak berpengaruh terhadap Real Earnings Management adalah penelitian dari (Sun et al., 2014) dan (Nasution dan Setiawan, 2007) sedangkan hasil penelitian yang berbeda dari penelitian ini adalah penelitian dari (Dhaliwal et al., 2010) yang menemukan bahwa Keahlian Keuangan Komite Audit berpengaruh secara negatif terhadap Real Earnings Management dan penelitian dari (Sun et al., 2014) yang menemukan bahwa Keahlian Keuangan Komite Audit berpengaruh secara positif terhadap Real Earnings Management.

Kualitas audit dalam penelitian ini diproksikan dengan ukuran KAP menggunakan variabel dummy dimana angka " 1 " diberikan kepada sebuah perusahaan apabila perusahaan tersebut diaudit eksternal oleh Kantor Akuntan Publik yang berafiliasi dengan KAP Big Four seperti Pricewaterhouse Coopers (PwC), Deloitte, KPMG, dan Ernst \& Young dan angka "0" diberikan kepada perusahaan yang tidak diaudit secara eksternal oleh KAP yang terafiliasi dengan KAP Big Four melainkan dengan KAP lainnya. Kualitas audit tidak mempunyai pengaruh yang signifikan terhadap real earnings management (REM).

Hal ini dapat disebabkan oleh rendahnya resiko litigasi atau litigation risk yang membuat motivasi auditor independen dalam memeriksa manajemen laba menjadi berkurang, hal ini memiliki kemungkinan untuk terjadi apabila area manipulasi laba mungkin berada di luar jangkauan tanggung jawab seorang auditor independen. Hasil penelitian yang menyatakan hal yang sama sebagaimana dengan hasil penelitian ini adalah penelitian dari (Khanh dan Kuong, 2018) dan (Piot dan Janin, 2007) yang menyatakan bahwa Kualitas Audit yang diproksikan dengan Ukuran KAP tidak berpengaruh terhadap 
real earnings management. Hasil penelitian ini berbeda dengan penelitian yang dilakukan oleh (Alves, 2012) dan (Chi-Sum dan Cheung, 2011) yang mengatakan bahwa Ukuran KAP memiliki pengaruh positif terhadap Real Earnings Management.

Profitabilitas merupakan sebuah tolak ukur yang sangat penting yang digunakan para pemegang saham dalam menilai kinerja sebuah perusahaan. Manajer dalam sebuah perusahaan memiliki motivasi untuk mencapai atau bahkan melampaui target pendapatan dan laba perusahaan (El Diri, 2017). Dalam hubungan antara pemegang saham dan perusahaan, hal utama yang dilihat oleh pemegang saham sebelum berinvestasi dalam perusahaan tersebut adalah Net Income atau laba tahun berjalan yang mewakili profitabilitas. Profitabilitas memiliki pengaruh yang positif secara signifikan terhadap real earnings management (REM). Hal utama yang dilihat oleh pemegang saham sebelum memutuskan untuk berinvestasi dalam sebuah perusahaan adalah profitabilitas. Semakin besar angka net income perusahaan tersebut akan menunjukkan semakin baik kinerja perusahaan sehingga pemegang saham percaya bahwa return yang akan didapatkan baik. Agar dapat menarik investor dan pemegang saham untuk berinvestasi di sebuah perusahaan, perusahaan memiliki kemungkinan akan melakukan real earnings management untuk menggelembungkan labanya.

Penelitian terdahulu yang memiliki hipotesis sama dengan hasil penelitian ini adalah penelitian dari (Khanh dan Kuong, 2018). Meskipun begitu, hipotesis dalam penelitian ini berbeda dengan hasil penelitian dari (Agustia dan Suryani, 2018) (Agustia, 2013) dan (Fandriani dan Tunjung, 2019) yang menemukan bahwa tingkat profitabililitas tidak memiliki hubungan dan tidak mempengaruhi real earnings management. Hasil penelitian ini juga berbeda dengan penemuan (Mohammadi et al., 2015) yang mengatakan bahwa tingkat profitabilitas berpengaruh negatif terhadap manajemen laba.

\section{KESIMPULAN}

Berdasarkan hasil pengujian dapat disimpulkan bahwa keahlian keuangan komite audit dan kualitas auidt tidak berpengaruh terhadap Real Earnings Management, sedangkan profitabilitas berpengaruh positif terhadap Real Earnings Management.

Keterbatasan yang ditemukan dalam penelitian ini adalah sebagai berikut : (a) Penelitian ini hanya terbatas dalam tiga variabel independen yaitu Keahlian Keuangan Komite Audit (ACFE), Kualitas Audit (AQL), dan Profitabilitas (ROA), dimana hal tersebut menyebabkan sempitnya ruang lingkup penelitian sehingga faktor-faktor dan variabel lainnya yang mungkin berpengaruh terhadap real earnings management (REM) tidak ikut dipertimbangkan; (b) Subyek dalam penelitian ini hanya terbatas dalam perusahaan manufaktur sehingga hasil penelitian ini kurang luas untuk dijadikan perwakilan dari keseluruhan berbagai sektor perusahaan yang terdaftar di BEI; (c) Rentang waktu yang digunakan dalam penelitian ini tergolong singkat yaitu dari tahun 2016 sampai dengan tahun 2018 sehingga kurang menggambarkan kondisi sebenarnya dalam perusahaan dalam jangka panjang.

Peneliti berharap dengan adanya keterbatasan tersebut, diharapkan penelitian selanjutnya dapat melakukan penelitian yang lebih baik lagi dan mengurangi terjadinya kesalahan sebelumnya. Peneliti menyarankan bahwa peneliti selanjutnya dapat menambah variabel-variabel dan mempertimbangkan penambahan variabel diluar perusahaan manufaktur yang dapat mempengaruhi Real Earnings Management (REM), sehingga 
cakupan menjadi lebih luas. Peneliti juga menyarankan agar peneliti selanjutnya dapat menambah sektor-sektor lainnya untuk digunakan dalam penelitian ini sehingga hasil penelitian dapat lebih mewakili keseluruhan sektor-sektor perusahaan manufaktur yang terdaftar di Bursa Efek Indonesia. Selain itu, peneliti selanjutnya juga dapat memperpanjang periode penelitian agar hasil penelitian dapat memberikan gambaran yang lebih menyeluruh dan dapat menggambarkan kondisi perusahaan manufaktur secara jangka panjang.

\section{DAFTAR PUSTAKA}

Agustia, D. (2013). Pengaruh Faktor Good Corporate Governance, Free Cash Flow, dan Leverage Terhadap Manajemen Laba. Jurnal Akuntansi dan Keuangan Vol. 15, 39.

Agustia, Yofi Prima., dan Elly Suryani (2018). Pengaruh Ukuran Perusahaan, Umur Perusahaan, Leverage, dan Profitabilitas Terhadap Manajemen Laba (Studi Pada Perusahaan Pertambangan yang Terdaftar di Bursa Efek Indonesia Periode 20142016). Jurnal Aset (Akuntansi Riset), 10(1), 2018. Hal. 63-74.

Alves, S. (2012). Ownership Stucture and Earnings Management: Evidence from Portugal. Australasian Accounting, Business and Finance Journal, Vol. 6, Article 12.

Alzoubi, E.S.S. (2017). Audit Quality, Debt Financing, and Earnings Management: Evidence from Jordan. Journal of International Accounting, Auditing and Taxation, 11(1). Page 51-76.

Boedhi, Nico Radityo dan Dewi Ratnaningsih. (2015). Pengaruh Kualitas Audit Terhadap Manajemen Laba Melalui Aktivitas Riil. KINERJA Volume 19, No. 1 Tahun 2015 Hal. 84-89.

Carcello, Joseph V. dan Neal, T.L (2000). Audit Committee Composition and Auditor Reporting. The Accounting Review, Vol. 75, No.4 October 2000 hal. 453-467.

Chi-Sum, W., Cheung M.F.Y (2011). Transformational Leadership, Leader Support, and Employee Creativity, Leadership \& Organization Development Journal. Vol. 32, No. 7, pp. 656-672.

Christiani, I., dan Nugrahanti, Y. (2014). Pengaruh Kualitas Audit Terhadap Manajemen Laba. Jurnal Akuntansi dan Keuangan, Vol. 16, No. 1, Mei 2014, 52-62.

Cohen, Daniel A. and Zarowin, Paul (2008), Accrual-Based and Real Earnings Management Activities Around Seasoned Equity Offerings. NYU Working Paper No. $2451 / 27554$.

Dhaliwal, Dan., Naiker, Vic., and Navissi, Farshid (2010). The Association Between Accruals Quality and the Characteristics of Accounting Experts and Mix of Expertise on Audit Committees. Contemporary Accounting Research Vol 27 No. 3. Page 787827.

El-Diri, Malek (2017). Introduction to Earnings Management. Springers Publishing.

Fandriani, V., dan Tunjung, H. (2019). Pengaruh Profitabilitas, Leverage, Ukuran Perusahaan dan Kualitas Audit Terhadap Manajemen Laba. Jurnal Multiparadigma Akuntansi, Vol. 1, No. 2, 505-514.

Ghozali, C. (2013). Teori Akuntansi. Semarang: Badan Penerbit Universitas Diponegoro. Gujarati, D.N (2012). Dasar-Dasar Ekonometrika. Terjemahan Mangunsong, R.C., Penerbit Salemba Empat, buku 2, Edisi 5, Jakarta.

Jensen, M. (1976). Theory of the Firm: Managerial Behavior, Agency Costs and Ownership Structure. Journal of Financial Economics, 305-306. 
Khanh, H., and Khuong, N. (2018). Audit Quality, Firm Characteristics and Real Earnings Management: The Case of Listed Vietnamese Firms. International Journal of Economics and Financial Issues, 2018, 8(4), 234-249.

Kim, Y., and Park M.S (2013). Real Activities Manipulation and Auditor's Client-Retention Decisions. The Accounting Review 89(1).

Mohammadi, Shaban., Ali Shirzad., and Reyhaneh Haghighi (2015). Earnings Management: Basics, Concepts Methods. LAP Lambert Academic Publishing.

Nasution, Marihot dan Doddy Setiawan (2007). "Pengaruh Corporate Governance Terhadap Manajemen Laba di Industri Perbankan Indonesia”. Simposium Nasional Akuntansi X.

Piot, C., and Janin, R. (2007). External auditors, audit committees and earnings management in France. European Accounting Review, 16(2), 429-454.

Primasari, Bardarita Pulung (2011). Analisis Pengaruh Kepemilikan Manajerial, Kepemilikan Institusional, dan Keputusan Pendanaan Terhadap Nilai Perusahaan (Studi Empiris pada Perusahaan Perbankan yang Terdaftar di Bursa Efek Indonesia periode 2007-2009). Skripsi Terpublikasi Universitas Sebelas Maret. Surakarta.

Sabrin, Buyung Satria., Dedy Takdir S dan Sujono (2016). The Effect of Profitability on Firm Value in Manufacturing Company at Indonesian Stock Exchange. The International Journal of Engineering and Science (IJES). 5(10). Pg. 81-89.

Sari, Ardiana Luthvita. (2017). Karakteristik Perusahaan, Tata Kelola Perusahaan, dan Manajemen Laba. Jurnal Akuntansi dan Bisnis, Vol. 15 No. 2, September 2017.

Sharma, Vineeta D and Chunli Kuang (2014). Voluntary Audit Committee Characteristics, Incentives, and Aggressive Earnings Management: Evidence from New Zealand. International Journal of Auditing. Hal 78.

Singgih, M.E., dan I.R. Bawono (2010). Pengaruh Independensi, Pengalaman, Due Professional Care, dan Akuntabilitas Terhadap Kualitas Audit (Studi pada Auditor di KAP "Big Four” di Indonesia). Simposium Nasional Akuntansi XIII. Purwokerto. Hal $1-24$.

Sun, Jerry., Lan, George., and Liu, Guoping (2014). Independent Audit Committee Characteristics and Real Earnings Management. Managerial Auditing Journal. Vol. 29 No. 2.

Susanto, Y. K. (2016). The Effect of Audit Committees and Corporate Governance on Earnings Management: Evidence from Indonesia Manufacturing Industry. International Journal of Business, Economics and Law, Vol. 10, Issue 1 (Aug.), 2.

Tala, O., dan Karamoy, H. (2017), Analisis Profitabilitas dan Leverage Terhadap Manajemen Laba Pada Perusahaan Manufaktur di Bursa Efek Indonesia. Jurnal Accountability, Vol. 06 No. 1, 2017.

Wardhani, R., dan Herunata, J. (2010). Karakteristik Pribadi Komite Audit dan Praktik Manajemen Laba. Simposium Nasional Akuntansi XIII.

Wiyadi. (2016). Pengaruh Asimetri Informasi, Leverage, dan Profitabilitas Terhadap Manajemen Laba Riil pada Perusahaan Manufaktur di Indonesia. ISSN 2407-9189. The $3^{\text {rd }}$ University Research Colloquium 2016. 